\title{
Adolescent Misconduct and the Juvenile Justice System
}

\author{
Rosemary C. Sarri \\ University of Michigan
}

Societal response to non-criminal behavior of adolescent youth has been an area of great concern for more than a century. However, despite considerable legislative and judicial action at state and federal levels, the problem has not abated, and, in fact, it may be more serious today than it has been in the past. For nearly two decades, this society has sought to constrain and limit the jurisdiction of the juvenile court over misconduct that was once a primary concern of that institution, namely that behavior which is illegal only for juveniles. Ever since the President's Commission on Criminal Justice convened in 1967 , a national effort has been underway to limit the court's jurisdiction. That effort culminated in the passage of the Juvenile Justice and Delinquency Prevention Act of 1974. In that legislation the Congress stated that it would provide grants to states which modified their handling of juvenile status offenders. Since then, substantial progress has occurred in the majority of states, but the problem continues and is far from solution. This is not a new problem, and perhaps that is why alternative policies and programs are so difficult to implement. Ever since Colonial times, the state has authorized the court to intervene to support the authority of parents and the

Rosemary C. Sarri, School of Social Work, University of Michigan, Ann Arbor, Michigan 48104. An earlier version of this paper appeared in Child Welfare Strategy in the Coming Years, Washington, D.C.: U.S. Department of Health, Education and Welfare, Office of Human Development, DHEW Publication No. (OHDS) 78-30158, 1978. 
integrity of the family as an economic unit. Despite the tremendous changes that have occurred in this society, the court jurisdiction over non-criminal misconduct continues widespread and is operative in all but a small minority of states. The juvenile court is also utilized to regulate parent-child relationships in significant ways, as has been noted by Mahoney (1974), Teitelbaum and Gough (1978), and others.

On the basis of the concept parens patriae, the juvenile court has been authorized to intervene wherever a juvenile's behavior is deemed problematic for the family, society, or even for the youth. Thus, behavior such as truancy, curfew violation, unruliness, incorrigibility, or even "idling one's time away" has been as sufficient a basis for the juvenile court to adjudicate a youth, as is the commission of a felony or misdemeanor. For more than 75 years, the court has processed juveniles with high proportions of status offenders in some courts and few, or none, in others. Only since 1977, with the more stringent amendments to P.L. 93-415, have states modified their behavior and, even now, only a small minority of states have amended their statutes to remove status offenses from the jurisdiction of the court.

\section{Who Are the Status Offenders?}

A status offender is commonly defined as a minor who engages in conduct that would not result in a criminal charge if committed by an adult. Typical examples are "truancy," "curfew violations," "promiscuity," "running away," "growing up in idleness," and "incorrigibility." Thus, status offenses refer both to specific behaviors and to general personality characteristics. They are "catchalls" for a youth's alleged pattern of stubbornness or rebelliousness. Although status offenders present no imminent threat to society, their conduct impairs their development, it is said; therefore, the state should intervene to constrain negative development. Few recognize that parental defiance and other forms of non-criminal misbehavior represent a youthful push for independence that is typical, but transitory.

Although empirical evidence is lacking, substantial information suggests that the proportion of status offenders pro- 
cessed and adjudicated as such by the juvenile court has risen substantially in the past decade (Lerman, 1970; Sarri \& Vinter, 1974; Spergel, Lynch, Korbelik, \& Reamer, 1979). There is reason to believe that youths in the United States are being subjected to increasing societal control (Gordon, 1978; Spergel et al., 1979).

Adolescence is well-recognized as a time for experimentation with life-styles, philosophies, modes of behavior, and challenges to the status quo by testing the agents of authorityschools, police, and parents (Constanzo \& Shaw, 1966; Erikson, 1967; Keniston, 1976). Today, instead of encouraging and tolerating experimentation that may produce more productive and capable adults, youth are subjected to more rigid authority in many community settings. Furthermore, in crowded urban communities high levels of conformity to adult behavior are required. Thus, an almost perfect setting for frustration and hostility is created. ${ }^{1}$

Although some have suggested that contemporary lifestyles of youth differ too radically from those of adults, students of history can point to numerous instances in the past where similar differences in perspectives prevailed. Perhaps of significance today is the observation that youthful expression is less tolerated because youth are not the economic resource for the society that they once were. As a result, they are expected to be docile and conforming to adult requirements. Donzelot's (1979) recent historical study of the relationship between industrialization and family structure is particularly provocative in this regard. He points out that the juvenile court has come to control both the family and youth for general social control goals, and that it really provides little assistance to parents who need support in child-rearing, except psychological counseling to further control.

\footnotetext{
${ }^{1}$ In an address to a convention of secondary school principals in Washington D.C. in February, 1976, President Gerald Ford admonished the educators to change their way of teaching so as to educate children to admire the nation's strengths, to correct its faults, "and to participate effectively as citizens... Young people in particular appear cynical and alienated from our government and legal system ... Too many Americans see the law as a threat rather than a protection." The operation of the juvenile justice system today does little to modify the juvenile's alienation or views of that system as a serious threat to their well-being.
} 
Contemporary society provides few legitimate opportunities for adolescents and young adults; the highest rates of unemployment are to be found in this age group (Westcott, 1979). It is not surprising that youth respond to this situation with great hostility and alienation. In turn, the adult society responds with even greater control-a self-defeating strategy. Not long ago, Keniston (1976) and Heyns (1976) argued that a new conceptualization of adolescence is urgently needed in the United States. Lay, as well as professional, observers now would concur that there has been little serious consideration of fundamental new approaches toward adolescent and young adulthood. Substantial proportions of adolescent youth can be expected to experience problems in growing up in a complex, unstable, and highly mobile society, where social supports for parents, as well as youth, are inadequate and inequitably available.

The majority of services available to youth and their parents today are directed toward intervention after problematic behavior has surfaced. Youth, then, are said to require "treatment" under the auspices of health, criminal justice, and other agencies. If society, instead, assumed that adolescent youth were a population at risk in specific sectors because of characteristics of the society, as well as particular attributes of the individuals, quite different policies and programs would be developed. For example, in the case of the health of the population, we no longer wait until a disease epidemic has emerged (e.g., measles, polio, cholera, etc.). Instead, we have, through public health programs, developed vaccines, sanitary water supplies, and so forth to prevent and control these diseases. A similar approach could be applied with respect to the expected socio-emotional health of adolescent youth.

\section{Statutory and Case Law re Status Offenders}

Any conceptualization of status offenders must inevitably consider the legal definitions outlined in the juvenile codes and the provisions which are established in both statute and case law to govern juvenile court behavior vis-id-vis these phenomena.

Statutory differences among the states are startling with 
respect to jurisdiction of the juvenile court with regard to:(1) age, (2) scope and nature of delinquent and status offense definitions, (3) offense limitations on the court's powers, (4) jurisdictional conflicts, and (5) permissible interaction with the adult system (Levin \& Sarri, 1974). As of 1977 all 50 states and the District of Columbia retained status offenders within the purview of the juvenile court, but the passage of the federal JJDP act stimulated many code revisions. In a number of states juveniles with selected characteristics are being removed from various areas of court control. Our earlier analysis as of 1972 revealed that 24 states and the District of Columbia had already developed separate categories for classifying status offenders (PINS, CINS, MINS, etc.), with eight other states having mixed categories (Levin \& Sarri, 1974). Since that time, many states have effected changes in their juvenile codes (Pennsylvania, 1977). Several have promulgated stringent limitations on the definition and processing of status offenses (e.g., Washington, Wisconsin, California, Pennsylvania, etc.).

The majority of states have fairly stringent prohibitions against placement of status offenders with other delinquents in correctional facilities. Often, however, status offenders may violate probation requirements or will be classified as not amenable to rehabilitation. In such cases, youth often are declared delinquent and in no way differentiated from other delinquents. Thus, statutory provisions do not protect against negative labeling and stigmatizing processes.

One illustration of these processes is provided by recent Florida legislation (Florida S.B. 165) which was initially heralded as a major reform. There, the new juvenile code essentially removed the status offender category known as CINS. Certain categories of status offenders (i.e., runaway, truancy, and ungovernability) were placed in a dependent child category. Services to them were to be provided by the public child welfare agencies on a voluntary basis. However, a major loophole was permitted in that the law states:

The first time a child is adjudicated as ungovernable, he may be treated as a dependent child and provisions relating to dependency shall be applicable. For the second and subsequent adjudication for ungovernability, the child may be treated and defined as delinquent. 
He or she thereby becomes subject to the full panopoly of juvenile correctional action, including institutionalization.

Due to the potentially damaging effects of labeling (Gough, 1978; Lemert, 1969; Mahoney, 1974; Piliavin \&c Briar, 1964; Sheridan, 1967), explicit reference to juveniles along with delinquents may well start the process of overcriminalization by failure to distinguish properly between categories of juvenile deviant behavior. As we will note subsequently, empirical evidence substantiates the claim that juveniles who are processed as status offenders differ in their deviant behavior patterns from those who are charged with more serious law violations (Carter, 1979; Isenstadt, Selo \& Barton, 1976; Spergel, et al., 1979). It is still possible, however, that an unruly child could be placed under supervision at age 12 and remain in that status until he or she reached the upper age limit of court jurisdiction, which in some states is as high as 21 years. Often such youths when placed under court jurisdiction react by "acting out" in ways which provoke subsequent court action; thus, the vicious cycle of "action-reaction" is underway. It seems quite clear that parsimony with respect to court intervention has substantially more empirical support than do liberal, early intervention policies, if the long-run goal is more effective socialization. As Rosenheim (1960) notes, neither society, nor the youth involved, benefit from the processing of these nuisances.

Statutory review indicates that status offenders are still largely viewed as misbehaving youth who require court intervention. The impact of the Juvenile Delinquency and Prevention Act of 1974 (P.L. 93-415), and amended in 1977, addresses the problem directly, but few resources are provided for handling these youth wholly outside the court. Statutes continue to predispose the judicial system to focus on referred youth rather than on the situations and conditions that precipitated the referral.

\section{Litigation}

Challenges to status offenses have arisen most frequently for the following reasons: (1) vagueness; (2) punishment of a condition; and (3) overbreadth. 
Void for Vagueness. The Supreme Court struck down statutes which "either forbid or require the doing of an act in terms too vague that men of common intelligence must necessarily guess at its meaning and differ as to its application" [Connally v. General Construction Co., 269 U.S. 385, 39 (1926)].

More recently, the U.S. Supreme Court, in vacating a California Federal District Court decision, held that the California juvenile statute was void because it granted juvenile court jurisdiction over children who were "in danger of leading an idle, dissolute, lewd, or immoral life." Such a statute was void, the court said, because it failed to give warning of proscribed conduct or information to the fact-finder to enable him to accurately recognize such conduct [Gonzalez v. Maillard, No. 50424 (N.D. Calif. Feb. 9, 1971), vacated 416 U.S. 918 (1974)].

Punishment of a Condition. In 1962, the United States Supreme Court, in Robinson v. California, 370 U.S. 660 (1962), reversed a conviction for violation of a California penal code, making it a criminal offense to "be addicted to the use of narcotics." The Court held that Robinson manifested a condition-"addiction"- which he was not able to control; thus, the defendant maintained a particular "status." Mr. Justice Douglas, in his concurring opinion stated:

We would forget the teachings of the Eighth Amendment, if we allowed sickness to be made a crime and permitted sick people to be punished for being sick. This age of enlightenment cannot tolerate such barbarous action (370 U.S. 678).

The effect of Robinson $v$. California was to support the argument that a status must be differentiated from a criminal act and that punishment for a status offense is in violation of the Eighth Amendment. This argument has continued to surface in cases involving convictions of chronic alcoholics for public intoxication [Easter v. D.C., 361 F.2d 50 (D.C. Cir. 1966), Driver v. Hinnant, 356 F.2d 761 (4th Cir. 1966), and the ultimate Supreme Court decision which upheld the constitutionality of convictions of chronic alcoholics for public intoxication, Powell v. Texas, 392 U.S. 514 (1968)]. 
The previous constitutional arguments attacked adult system practices, punishing status rather than behavior. In the past decade, there have been similar attempts to confront statutes applicable to juveniles. In Gesicki v. Oswold, 336 F. Supp. 371 (S.D.N.Y. 1971), the Wayward Minor Statute of New York was declared unconstitutional. The act granted adult criminal jurisdiction over youth 16 through 21 who were punished for being "morally depraved" and "in danger of becoming morally depraved." The court stated that Wayward Minor Statute permitted "the unconstitutional punishment of a minor's condition rather than of any specific action."

On the other hand, decisions have supported statutes permitting intervention. In Blandheim $v$. State of Washington, 529 P.2d 1096 (1975), the Washington Supreme Court upheld the constitutionality of that state's incorrigibility statute and ruled that punishment for this offense was not cruel and unusual. (In this particular case a 17-year-old female had run away from home and various placements eight times in three months.) The statute read:

An incorrigible child is one less than 18 who is beyond control of his parents, guardian, or custodian by reason of the conduct or nature of said child.

The girl contended that the statute punished the "status" of being incorrigible in violation of the Eighth Amendment. The court, although not denying that incorrigibility is a condition or state of being, justified the statute's legitimacy by stating that one acquires such a status only by reason of one's conduct or a pattern of behavior proscribed by the statute. Engaging in conduct that placed her beyond the lawfully exercised control of her mother was felt to be sufficient basis for support of an adjudication of incorrigibility. The court, however, did not show awareness of parental involvement, nor did it acknowledge that the parents also could have been charged.

In 1977, the Supreme Court of Appeals in West Virginia utilized constitutional standards rather than a statutory interpretation, as in the In re Ellery C. Case. In State ex rel Harris i. Calendine, 223 S.E. $2 \mathrm{~d} 318$, the Court ruled that incarceration of status offense youth in institutions with delinquents violated 
guarantees of equal protection, due process, and protection against cruel and unusual punishment. These holdings were subsequently enacted into statutes in West Virginia.

Overbreadth. This may be another basis for an attack on status offense statutes. In the case of State v. Mattiello, 4 Conn. Civ. 55, 225 A.2d 507 (App. Div. 1969), the court upheld a conviction of a female juvenile for violation of the Connecticut statute, "forbidding walking with a lascivious carriage." The Appellate Division upheld the statute as valid under the concept of parens patriae, that the preceding was civil rather than criminal, and that its end was not to punish, but to rehabilitate the child through guardianship and protection.

Another form of overbreadth has existed in the institutionalization of status offenders with delinquent youth. In In re Ellery C., 32 N.Y.2d 588 (1973), the New York Supreme Court concluded that confinement at a public training school was not appropriate supervision or treatment. It further ordered the Department of Youth Services to provide adequate treatment, but it did not specify how PINS should be supervised. Therefore, the findings of the Institute of Judicial Administration (1975) were not surprising. They observed that the separation requirements failed to make any subsequent improvement in the care of troubled children.

In a subsequent case, In re Lovette $M ., 35$ N.Y.2d 136, 359 N.Y.S.2d 41 (1974), the Court of Appeals refused to hold that placement of a PINS in a training school was unlawful per se, stating that:

It is confinement of PINS children in a prison atmosphere along with juveniles convicted of criminal acts that is proscribed and not the fact of placement in a training school. (p. 141)

Similar cases in other states demonstrate that legislative restriction does not prevent the use of private institutions or community-based residential facilities by the court: In Gary $W$. v. Stewart, No. 74-2412 (E.D. La., filed December 30, 1974), the transfer of 400 youth to private institutions in Texas was challenged. Obviously, barring commitment of status offenders to public institutions is only a partial solution, since 
private facilities-even so-called community-based programsmay infringe as much on individual liberty as the public institution or public detention facility.

\section{The Contemporary Scene}

Numbers of Youth. Status offenders presently are processed as juvenile delinquents in the majority of states, but because adequate information procedures are lacking at local, state, and national levels, it is not possible to report accurately even the total number of juveniles who are processed through the justice system each year. In $1977,1,355,490$ delinquency cases were processed by the nation's juvenile courts, based on voluntary reports to the National Center for Juvenile Justice (NCJJ, 1980). If we add to that some estimate of the numbers in non-reporting counties plus those held in jails, institutions, and detention facilities, one can easily produce an estimate in excess of two million cases. There is no way to determine the extent of overlap-and, therefore, no reliable means of estimating the unduplicated count of individuals. However, given the estimated child population of 29.5 million between the ages of 10 and 18 in 1972 in the Lnited States, the overall rate of processing is 45.9 cases per 1,000 potentially processed as delinquent each year (NCJJ, 1980). Moreover, if we were to concentrate on the more vulnerable years of 12 to 18 , the proportions would exceed one in 15. Data from NAJC survey of 400 juvenile courts corroborate this estimate of the level of intervention (Sarri \& Hasenfeld, 1976). Three-fourths of the cases processed are males, producing a rate of 69 per thousand for them versus 21.8 for females.

\section{Contemporary Court Processing and Disposition}

What proportion of the cases are status offenders? Again, that proportion can only be crudely estimated because of the lack of adequate information systems. But, from the national study of juvenile courts and correction facilities conducted by the National Assessment of Juvenile Courts, we can conservatively estimate the proportion at $30 \%$. Thus, approximately 


\section{TABLE 1}

Juvenile Referrals by Offense and Detention Rate, Hennepin

County, Minnesota, 1974

\begin{tabular}{lcc}
\hline \multicolumn{1}{c}{ Charge } & Number Referred & $\begin{array}{c}\text { Number Detained } \\
\%\end{array}$ \\
\hline Incorrigibility & 472 & 82.8 \\
Truancy & 16 & 75.0 \\
Absenting (runaway) & 1790 & 72.8 \\
Robbery & 162 & 77.2 \\
Assault & 172 & 59.9 \\
Burglary & 531 & 50.8 \\
\hline
\end{tabular}

Source of Data: Community Welfare Council, Hennepin County, Minnesota: Hennepin County's Status Offenders: A Preliminary Report. January 9, 1976.

600,000 status offense cases can be expected to be processed and/or served through the juvenile courts and correctional programs of the United States each year. ${ }^{2}$

Variations among counties within a state are large, with some having fewer than $10 \%$ of their caseload in status offenses and others having as high as $60 \%$. Thus, one cannot expect to find a similar pattern within or between states. Studies by Lerman (1970) and Sarri and Hasenfeld (1976) and Sarri and Vinter (1974) document the disproportional representation of status offenders in detention, as does a Hennepin County, Minnesota report of court referrals and detention (Community Welfare Council, 1976). Minnesota is one of the states in which no distinction is drawn between status offenders and youth charged with felonies and misdemeanors. In $1974,45.6 \%$ of all referrals to the court were status offenders, but they constituted $55.8 \%$ of all who were admitted to detention. The data in Table 1 illustrate the strict control of status offenders in this metropolitan county.

These findings are particularly disturbing because they show a very high rate of detention for all juvenile cases, but

${ }^{2}$ The National Advisory Commission on Correctional Standards and Goals (1973) estimated that $40 \%$ of the dispositions of the juvenile court involved status offenders. More than twenty years ago William Sheridan (1965) surveyed a sample of correctional institutions and found that $30 \%$ of the youth were committed for conduct which would not have been criminal had they been adults. NCJJ (1980) report a total of $37 \%$ of all cases in status and other categories. 
especially for those who present no threat to the community. This is in sharp contrast to the case of adult jailing, where it is commonly accepted that persons are to be held only if the public will be endangered by their release, or if there is reasonable evidence to believe the person will abscond. ${ }^{3}$

These data also illustrate the impact of variable organizational strategies, for only 16 youth were referred for truancy in Hennepin County. Given the numbers of youth in school in the county, this number is far below that which would typically be expected. Thus, it is probable that schools in Minneapolis and other communities in the county have utilized alternative strategies for dealing with school truants.,

It was possible to estimate that $33-35 \%$ of the committed youth in correctional facilities, as of 1974 , were status offenders (Grichting, 1975; U.S. NCJ ISS, 1978). ${ }^{6}$ The data in Table 2 is from a nationally representative sample of correctional programs studied by the National Assessment of Juvenile Corrections, which enabled us to determine whether status offenders and juvenile delinquents were separated during disposition. The sample consists of 20 public and 22 private facilities for adjudicated youth. Thirty-seven of the 42 facilities were located in states which in 1972 required, by statute, the separation of these youth during disposition. Only two out of

\footnotetext{
${ }^{3}$ These findings are also alarming because Minnesota is one of the states with extensive child welfare programs. Clearly many of the youth processed through the court and detention in Hennepin County could be served more appropriately by child welfare agencies.

"The situation of the "runaway" is particularly disturbing when contrasted with truancy, for "runaways" constituted $57 \%$ of this sample. The size of the number given the population of this community suggests that the court was the first agency involved rather than the one of last resort.

${ }^{5}$ The 601 Diversion Project Report (Baron \& Feenev, 1972) provides findings to support for early and flexible intervention to help families solve crisis problems when they arise. This project was directed toward status offenders (classified as 601's in the California Juvenile Code). It demonstrated that these youth can be diverted successfully from the court and that subsequent contact will then be reduced.

${ }^{6}$ Data from Children in Custody for 1971, 1973 and 1974 (NCJ ISS) indicate that while some states have made marked changes in the processing of status offenders, the overall picture is one . . which one-third or more continue to be processed through juvenile courts and held in some type of program facility. The experience of New York in In Re Ellery C. provides little reason for optimism with respect to the outcomes of differential handling.
} 
TABLE 2

Distribution of Offenders by Type of Correctional Facility

\begin{tabular}{|c|c|c|c|c|c|c|}
\hline & \multicolumn{2}{|c|}{ Institutions } & \multicolumn{2}{|c|}{ Open Programs } & \multicolumn{2}{|c|}{ Total } \\
\hline & $\%$ & (n) & $\%$ & (n) & $\%$ & (n) \\
\hline $\begin{array}{l}\text { Juvenile delinque } \\
\text { Status offenders }\end{array}$ & $\begin{array}{l}84.9 \\
66.5\end{array}$ & $\begin{array}{l}(792) \\
(355)\end{array}$ & $\begin{array}{l}15.1 \\
33.5\end{array}$ & $\begin{array}{l}(141) \\
(179)\end{array}$ & $\begin{array}{l}100.0 \\
100.0\end{array}$ & $\begin{array}{l}(933) \\
(534)\end{array}$ \\
\hline Total & $\overline{78.2}$ & $\overline{(1,147)}$ & 21.8 & $(320)$ & $\overline{100.0}$ & $\overline{(1,467)}$ \\
\hline
\end{tabular}

Source of Data: National Assessment of Juvenile Corrections, University of Michigan, Ann Arbor. Michigan, 1976.

the 37 did not have a mixture of both types of offenders. The two exceptions, one public and one private, had a client population of less than seven offenders. Our observations clearly indicate that separation essentially does not exist. The actual situation, which is in accord with the findings of the Institute of Judicial Administration (1975), is clearly in violation of the letter and the spirit of the law.

Since the implementation of the 1977 Amendment to the JJDP Act, states receiving grants under that legislation were to reduce the holding of status offenders by $75 \%$ in order to be in compliance. The majority of states have committed substantial resources to that goal and many have achieved compliance. Data from the national evaluation of the Deinstitutionalization of Status Offender Projects is now underway and will reveal the extent to which the goals have been achieved nationally. However, recent complimentary studies by Lerman (1980) suggest that what may have been achieved is only a recycling of youth from public training schools and detention centers to private institutions and mental hospitals.

Table 2 further indicates that the majority of both law violators and status offenders end up in institutions, although there is a greater tendency to place delinquents in institutions.

When comparisons are made by sex, as in Table 3 , it is evident that proportionately more females than males are committed for status offenses. Of course, males outnumber females by more than two to one, but given the fact that the arrest ratio of males to females is 4 to 1 , the disproportionate institutionalization of females is readily apparent. A 1974 study in Louisville reported status offenses accounted for $46 \%$ of female re- 
TABLE 3

Commitment Offense, by Program Type and Sex (in percentages).

\begin{tabular}{|c|c|c|c|c|c|c|c|}
\hline & $\begin{array}{l}\text { Status } \\
\text { offense }^{d}\end{array}$ & $\begin{array}{c}\text { Probation } \\
\text { or parole } \\
\text { violation }\end{array}$ & $\begin{array}{l}\text { Mis- } \\
\text { demeanor }\end{array}$ & $\begin{array}{l}\text { Drugs } \\
\text { or } \\
\text { ralcohol }\end{array}$ & $\begin{array}{l}\text { Prop- } \\
\text { erty }\end{array}$ & Person & $(n)$ \\
\hline \multicolumn{8}{|l|}{ Institution } \\
\hline Male & 23 & 4 & 2 & 6 & 46 & 18 & (832) \\
\hline Female & 50 & 1 & 3 & 18 & 14 & 14 & (349) \\
\hline \multicolumn{8}{|c|}{ Community } \\
\hline Resident & & & & & & & \\
\hline Male & 50 & 3 & 1 & 10 & 26 & 10 & $(70)$ \\
\hline Female & 67 & 3 & 0 & 14 & 12 & 3 & $(58)$ \\
\hline \multicolumn{8}{|c|}{ Day treatment } \\
\hline Male & 45 & 3 & 4 & 6 & 30 & 12 & (164) \\
\hline Female & 87 & 0 & 0 & 5 & 3 & $j$ & (37) \\
\hline
\end{tabular}

Note: Determination of commitment offense was based on youth response to the question, "Why were you sent here?"

"Status offenses include incorrigibility, dependent and neglected, truancy, running away, curfew violations, disorderly, etc.

Source of Data: National Assessment of Juvenile Corrections. Universitv of Michigan, Ann Arbor, Michigan, 1976.

ferrals, with more detention and institutionalization of females, despite the fact that their offenses were far less serious (Juvenile Justice Digest, 1976). Data from that same city indicated that "home detention" was as effective as other forms despite the reluctance to utilize it in many communities. ${ }^{7}$

Responses of youth in the National Assessment of Juvenile Corrections sample of correctional programs permitted some examination of the labeling and stigmatization process. Youth were asked why they were sent to the program in which they were placed and if they perceived that "people think of me as a criminal because I'm here." The latter question measures subjective perception of labeling. Responses were analyzed with reference to several variables, including patterns of official intervention, type of program placement,

${ }^{7}$ Until recently many jails incarcerated "alcoholics" or "drunks" in a manner similar to the handling of status offenders but with the passage of decriminalization statutes pertaining to alcoholic beverages, this practice has declined sharply. Moreover, the Supreme Court decision in Robinson v. California 370 U.S. (1962) forbade punishment for being ill as was noted earlier. 
staff-youth interaction patterns, and personal characteristics of youth.

Analysis of youth responses reveals that $50 \%$ of the youth thought that they were considered criminal. Among first offenders, $34 \%$ held these opinions, but there was no significant difference between youth initially committed for status rather than criminal offenses. Fewer females than males believed that they were considered criminal ( $46 \%$ versus $55 \%$ ), but there was a smaller difference for females when offense was controlled. The subjective probability of being labeled criminal increases proportionally to the frequency and types of contact between youth and the justice system. These findings provide considerable support for the recommendation of parsimony regarding the extent of intervention with respect to status offenders (Grichting, 1975).

A recent study in the Family Court of New York of "ungovernability" cases indicates that $62 \%$ of these youths are females in mid-adolescence, disproportionately non-white and from large, poor, and single-parent or broken families ("Comment," 1974). They also observed that $37 \%$ were "neglected" but classified as "ungovernable" in order to expedite processing. Sixty-eight percent of these youths were held in secure detention, despite its obvious impropriety. Finally, they observed that higher proportions of these youths were adjudicated and committed to residential facilities than were youth who committed serious property or person crimes. A study of the Michigan Department of Social Services drew similar conclusions about institutional placement of non-aggressive youth (Michigan, 1975).

The New York and Louisville studies document another frequent observation regarding status offenders. Those who wind up in the juvenile court and correctional programs are disproportionately poor and minority youths whose parents lack needed emotional and economic resources. For many young people-particularly those residing in the inner city ghettos-the law is an omnipresent fact of daily life. It is estimated in some cities that $90 \%$ of these young people will have been arrested at least once before the age of 18. Such a statistic is shocking in terms of the level of punitive social control being exercised over these youths. Even a police state 
would not function properly if it were required to maintain forcible control over $90 \%$ of the population.

At a time when support for the institution of the family is precarious, the formalized coercive intervention by the court serves to undermine family authority, isolates the children from parents and encourages parents to abdicate their roles (Gough, 1978; Mahoney, 1974). Court intervention actually may constrain the range of services available to youth and their family because the school and community agencies will be quite willing to allow the court to handle the situation fully. As. Gough (1978) noted, there are several studies that support these observations that the court has been utilizing to regulate parent-child relationships in ways that have produced negative outcomes.

Youths from middle and upper income families may be arrested for status misconduct, but they are handled informally in nearly all cases. Parents arrange for special counseling, private schools, and so forth. Incarceration and court sanctions can be avoided by those who have the necessary resources. The care of other youths turned over to authorities by their families is particularly disturbing, for these youths are frightened, confused and often alienated from close interpersonal relationships. They feel angry and abandoned. In this state they are dealt with by law enforcement agencies and the court in a rigid and punitive manner; seldom is anything done to relieve their anxiety, depression or anger. It is quite obvious that the court is not the proper agency to deal with family problems presented as status offenses. In California, the Sacramento Community Crisis Intervention Program has demonstrated that alternative forms of intervention could be successful in alleviating family problems so that court action is unnecessary (Baron \& Feeney, 1972).

One unfortunate consequence of present approaches to the problems of the status offender is that it is very easy to enter the juvenile justice system, but once inside, it is very difficult to exit. Laws governing non-criminal behaviors provide parents, schools, and community agencies with easy access to the court for the purpose of their taking action toward a juvenile. Research findings now indicate that one of the likely outcomes from this intervention may be socialization 
toward more serious delinquency. Study findings are mixed with respect to subsequent recidivism by status offenders and other youths charged with more serious delinquency (Clarke, 1974; Heuser, 1979; Spergel et al., 1979). But, it does seem clear that youth are not benefitted because of court intervention and that may be the most significant criticism of present policies regarding status offenses. In a longitudinal and comprehensive evaluation of diversion programs in Illinois, Spergel and his colleagues have stated that youths who receive crises services at home have fewer subsequent contacts with the juvenile justice system than those held in detention, group homes, or institutions. (Spergel et al., 1979). The less intrusive the alternative, they note, the fewer subsequent justice system contacts of all types. The Chicago group also observed that the system is particularly problematic for females who tend to be chronic "pure types," and yet they are disproportionately placed in detention and held in institutions for longer periods of time. They commented that, "chronic status offense behavior is mainly a sex role and to some extent a family problem" (p. 87).

It appears that the type of community is more critical in the selection of girls for processing. Higher levels of processing of females were observed in middle and upper class communities. In contrast, the phenomenon of "widening the net" was observed more often in lower SES communities in Illinois. But Spergel et al. (1979) also commented:

Regardless of the type of community, a youth officer is more likely to adjust a delinquent with a prior record and permit him or her to remain in the community, than a status offender with a prior record. (p. 91)

It is often said that the court is at the top of a pyramid of agencies which may intervene into a juvenile's life. Resort to the court is said to be the "last resort," but unfortunately, this appears to be an incorrect observation today. Many first offenders are dealt with as stringently as those with multiple charges and many youths in the juvenile justice system have relatively little prior contact with social welfare agencies, so that they lack knowledge of diversion alternatives. 


\section{Policy and Program Issues}

Policy. Implementation of Sec. 223 of the Juvenile Justice and Delinquency Prevention Act of 1974 (P.L. 93-415) which requires that status offenders not be co-mingled with other delinquents or held in secure custody has produced significant policy changes in many states. However, the momentum is uneven and the 1977 amendments grant the states up to five years for full implementation. Moreover, most states have been reluctant to remove status offenders from the jurisdiction of the juvenile court with the result that the final outcomes may be far less than was anticipated by Senator Bayh and the other sponsors of the legislation.

Given priorities for the development of prevention and diversion policies and programs vis-à-vis status offenders, numerous issues arise as to how and by whom these policies should be implemented. With a particular regard to diversion, it is important to understand how this policy can result in viable referral out of the justice system, rather than "lesser penetration" and then referral out. The evidence from Williams and Gold (1972); and Gold and Reimer (1975) suggest clearly that avoidance of any contact with the justice system is to be fostered if subsequent delinquent behavior is not to increase. Resources for prevention strategies have been reduced at federal and state levels in the past decade. Without such efforts, effective diversion is not likely to occur for the majority of youths needing alternative community services.

Rates of crime committed by youth had been rapidly increasing, but reliable objective measurement of this increase was never completed. Particularly disturbing were the reports of increases in violent crime by youth. These reports are leading to punitive policies in many states despite the lack of reliable and valid evidence about the phenomenon. Youth populations are now declining rapidly, but policy decisions may be more reflective of the past than the present and future.

Levine (1973), Wald and Schwartz (1974) and others have suggested that if responsibility for status offenders is transferred from the juvenile court to child welfare or other social service organizations, policies must be initiated to assure protection of individual rights and provision of effective services. 
They argue that the past conduct of some of these agencies have been such that serious questions can be raised about their capability and accountability in the provision of quality services. Given the findings from the study of the New York Family Court ("Comment," 1974), one has little reason for optimism, unless there are changes in the existing policies and practices of public social service agencies for children.

The inability and inappropriateness of the state's attempt to legislate or enforce morality is a policy issue of importance throughout the United States. Nowhere is this more apparent than in issues relating to laws and policies governing children's conduct. When powerful, widely available media such as television and films challenge moral norms in extremely provocative ways, it is difficult for the state to use the juvenile court to enforce behavior contradictory to that which is advocated in the media. Our current situation is a "Catch 22" for adolescent youth: use of the juvenile court to enforce moral norms no longer acknowledged by the adult society will not only be ineffective, but will also jeopardize the court's legitimate operation as a judicial agency. Adherence to law is dependent on voluntary assent by the majority of the population. If youth perceive the court as attempting to enforce moral norms not adhered to by adults, they are likely to lower their valuation of the agency.

Juvenile court staff have expressed views about which agencies should handle categories of behavior now under the jurisdiction of the court. The findings in Table 4 from a National Assessment of Juvenile Corrections survey of a sample of 400 juvenile courts report on the views of judge and probation officers about status offenses, misdemeanors, and felonies. Probation officers, more frequently than judges, said that status offenders should be removed from the court and be handled by a nonjudicial agency. Judges and probation officers agree that truancy is best handled nonjudicially, but differ about running away and promiscuity. Probation officers are those staff most directly involved in service delivery to these youth so their responses have particular relevance. Among the judges who responded, those who spent at least $35 \%$ of their time on juvenile matters were more likely to hold views similar to those of probation officers. These responses 
TABLE 4

Juvenile Judge's and Probation Officers' Preferred Jurisdiction over Certain Offenses Committed by Juveniles. ${ }^{2}$ In percentages of Judges $(n=252-269)$ and of Probation Officers $(n=469-491)^{b}$

Nonjudicial $\frac{\text { Juvenile court }}{\text { Judges P.O.'s Judges P.O.'s Judges P.O.'s }}$

\begin{tabular}{lrrrrrr}
\hline Status Offense & & & & & & \\
$\quad$ Truancy & 44 & 35 & - & - & 56 & 65 \\
$\quad$ Promiscuity & 54 & 35 & - & - & 46 & 65 \\
$\quad$ Running away & 61 & 47 & - & - & 39 & 53 \\
& & & & & & \\
$\quad \begin{array}{l}\text { Misdemeanor } \\
\text { Liquor violation }\end{array}$ & 81 & 68 & 5 & 4 & 14 & 27 \\
$\quad$ Vandalism & 94 & 95 & 2 & 2 & 4 & 3 \\
$\quad$ Shoplifting & 94 & 90 & 2 & 2 & 4 & 8 \\
& & & & & & \\
Felony & 69 & 58 & 31 & 42 & $<0.5$ & $<0.5$ \\
$\quad$ Armed robbery & 94 & 96 & 5 & 3 & $<0.5$ & 1 \\
$\quad$ Breaking \& entering & 94 & 91 & 7 & 9 & 1 & 0.5 \\
\hline Auto theft & 92 & 91 &
\end{tabular}

${ }^{2}$ Numbers vary due to responses that could not be classified into either of the three choices listed.

buestion: Which of these problems do you feel are best handled by the juvenile court, an adult court, or other social agencies (schools, child welfare, etc.)?

further suggest that the greater the contact with status offense situations, the more likely it is that court personnel will state that this non-criminal behavior should be handled by a nonjudicial agency.

Program Issues. Institutional placement of youth for noncriminal status behavior is still prevalent in the majority of states despite numerous recommendations for alternative community-based programming. However, experience of those states with variable community-based programs indicates that they can be viable and effective for the majority of youth. Moreover, there are no conclusive data which suggest that the overwhelming majority of youth would not accept needed services if they were offered voluntaristically. The experience of many innovative community-based programs for youth clearly indicates a high level of receptivity to these services. Unfortu- 
nately, and in contrast to adult program planning, many public statements continue to be made by both professional and lay leaders that coercion is necessary in programming for youths charged as status offenders.

Because of the frequency of assertions that status offenders actually commit acts equally serious to those committed by other delinquents, the findings in Table 5 are relevant. Judge Lindsay Arthur (1975) advocated juvenile court intervention because, he asserted, status offenders do not differ in their behavior from other delinquents. The national sample of youth studies by the National Assessment of Juvenile Corrections were asked to report how many times prior to their present placement they had engaged in various deviant behaviors. The findings make it quite clear that youths who are committed for person or property offenses report that they have engaged in law violative behavior far more frequently than those who were committed for status offenses. Only in the case of "running away" was there any exception to this pattern, for $37 \%$ of the "status offenders" reported running away 3 or more times, while $35 \%$ of the "property" and $33 \%$ of the "person" offenders so reported. In contrast, $20 \%$ of the status offenders reported 3 or more times of "breaking and entering," but $59 \%$ of the "property" offenders and 54\% of the "person" offenders reported this incidence of committing B \& E's.

The problematic nature of school-youth interactions are clearly evident in these data for $39 \%$ of the status offenders, $52 \%$ of the property and $61 \%$ of the person offenders reported being suspended 3 or more times. These data also refute the assertion of Judge Arthur that there are no differences between status offenders and youths committed for felonies and misdemeanors. Of course, all youths reported frequent anti-social acts, but these responses are in accord with those obtained by Gold and Riemer (1975), and Williams and Gold (1972), and Spergel et al. (1979).

When youths were asked about antisocial behavior following their placement in a correctional program, such behavior increased substantially for status offenders the longer they

${ }^{8}$ See Isenstadt et al. (1976) and Vinter, Kish, and Newcomb (1976), pp. 4143 and $98-101$. 


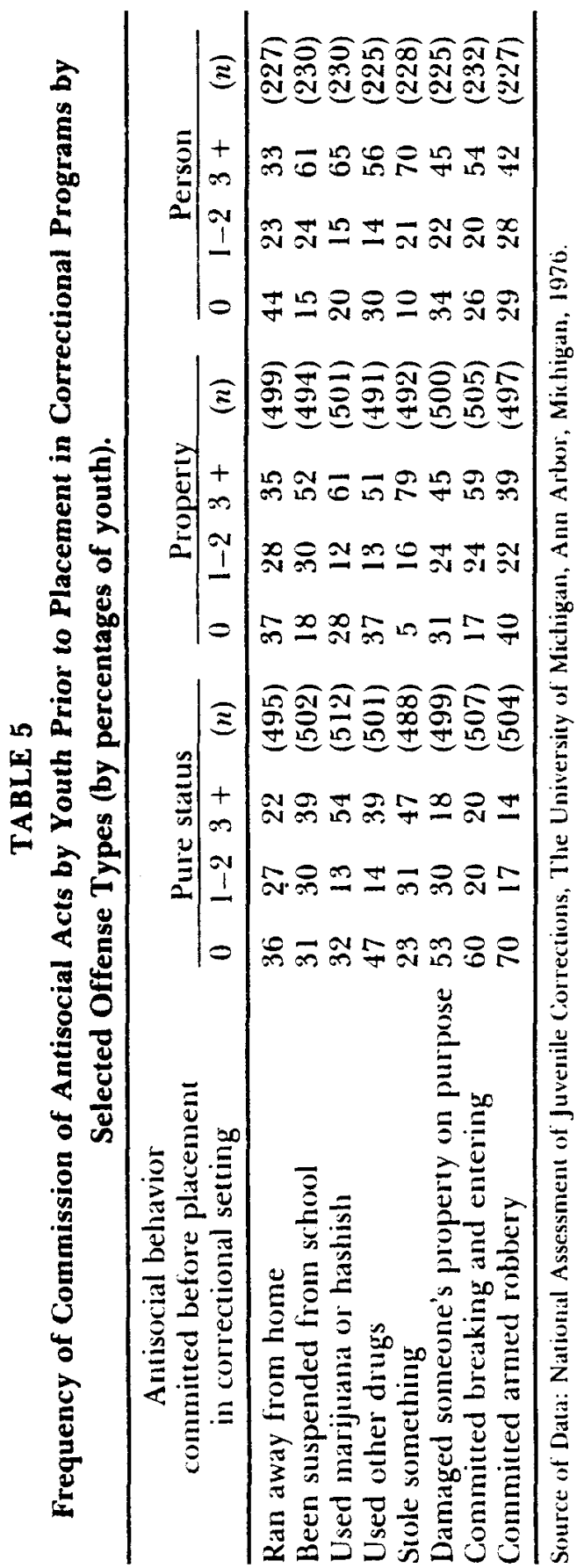


were placed in correctional programs. Thus, the interaction appeared to have resulted in socialization to criminal behavior.

The survey of alternative programming for status offenders in Illinois revealed some critical programming dilemmas (Lynch, Korbelik, \& Spergel, 1977). Over $80 \%$ of the status offenders who were apprehended had no previous involvement with the justice system. Despite that fact, they were more likely to be detained than youth charged with delinquent offenses even when the latter had several prior offenses. Lynch et al. (1977) concluded that "Status offense behavior is not pre-delinquent behavior" for youths tended to 'specialize' in different types of deviancy." Their apprehension by police reflected the type and amount of resources in the community, rather than actual incidence of problematic behavior. They recommended greater parsimony in processing by police and courts, plus development of more general local community service agencies for youth.

\section{The "Expansion" Hypothesis}

The development of programs which are alternatives to incarceration appear to be a "mixed blessing" in the case of status offenders, unless these youths are wholly removed from the juvenile court jurisdiction for processing and programming. The experience of New York, with respect to the processing of PINS cases, was largely ineffective, according to the analyses completed by the Institute of Judicial Administration (1975); the report of Elizabeth Schach (1973); and the study of ungovernability cases in the Family Court ("Comment," 1974). Similarly Vinter, Downs, and Hall (1976) observed that as states moved to deinstitutionalize juvenile offenders, the results often were increased numbers of youth under the supervision of the courts and correctional agencies. Most recently, Spergel et al. (1979) in their preliminary evaluation of the status offender alternatives project in Illinois noted that while the project was very successful in reducing detention in Cook County, there was a $53 \%$ increase in police referrals of status offenders to the juvenile court. They noted that police were apparently casting a wider control net, since there was no independent evidence of changed behavioral patterns among 
youth. Clearly, these findings all suggest that there have been negative unanticipated consequences from the development of new programs and policies for status offenders, while still keeping them under juvenile court jurisdiction and relying on police as the primary referral source. The Illinois project also noted that where youths were dealt with wholly outside the legal system, the service was fully as adequate, often better, and there did not appear to be negative consequences in the form of labelling, differential association, and so forth. It is most unfortunate that juveniles who are from poor neighborhoods and single-parent households are more likely to be apprehended for status behavior, whereas, in middle class and two-parent households, voluntary community services are provided for youths who engage in such behavior. Data which are available, although inadequate, indicate rather clearly that the latter alternative is preferable, both in terms of short-term and long-term outcomes.

\section{Action Strategies}

The National Scene. The federal government and national youth organizations have until very recently given little attention to adolescent youth socialization policies, especially for youths identified as status offenders. Statutory changes and new proposals now provide significant opportunities for both. This society urgently needs an assertion of moral, political and normative leadership at the national level. The strategy proposed here is contrary to programs which have developed under general and special revenue sharing where the federal government assumed minimal responsibility for how the monies were spent locally. Experience with LEAA Block Grants was very poor with respect to proportional allocation of funds for youth services as Melekos (1976) points out. The federal government has the capability to perform four major functions needed to buttress and improve youth programs across the nation:

1. Establish priorities, standards and guidelines for comprehensive youth services. The products of the National Advisory Commission on Correctional Standards and Goals and of the Na- 
tional Commission on the Mental Health of Children provide exemplars which need to be extended to cover youth services generally. The formulation of guidelines regarding the rights of minors to social services must be done at the national level in a society that is as mobile as that of the United States. Inter-agency exchange and communication is needed at the federal level through mechanisms such as interdepartmental committees on families and children. Initiative for this effort is appropriately the responsibility of the Departments of Education, Labor and of Health and Human Services. One can hardly expect coordination at the state and local level when such coordination is nearly non-existent at the federal level.

2. Channeling resources for strategic aims. This society assigns a very low priority to policies and programs for youth. In fact, several authorities have commented that the United States as a society "dislikes" children, given the types of social programs for youth which are supported. Youth are the nation's most valuable resource, but at present, nationally, they fall far below energy, the environment, and military defense in any listing of priorities. Moreover, programs and resources are far more readily available for adults than for youth. Recent reports of the U. S. Census Bureau indicate that children are the most rapidly increasing age group of poor-now surpassing the aged, because of recent changes in Social Security legislation.

3. Fostering innovation, experimentation and evaluation in programs for youth. The United States lacks a coherent theory of adolescent socialization which can be applied now and during the next quarter century. Although many have argued for more research support for study of this problem, of equal value in the development of such a theory would be careful innovation and evaluation of new programs and services.

Already underway in some states are a number of creative innovations which provide the basis for developing new policies and guidelines. Further federal encouragement of these efforts is needed, and, following that, wide dissemination of results, so that other communities have information for more rational decision-making. Our knowledge is such that one could not be optimistic about the development of program models, but at least some effort could be extended in 
that direction. The support for innovative programs, however, should not jeopardize existing policies around which some consensus has been developed-for example, deinstitutionalization and the use of the least restrictive alternatives in programming, decriminalization of status offenses, and diversion of youth to voluntary community programs.

4. Develop a national information infrastructure. The barriers to policy-making and program development result in important ways from the lack of systematic, comparative and reliable information about patterns, trends, etc. Few states have been able to develop information systems, but even where they have, they are deprived of more general information from outside their own jurisdictions. Lacking such information, administrators, legislators and planners proceed on the basis of intuition, experience, revelation or reactive response to public pressure. ${ }^{9}$

Among other things, information is needed on: censuses of the populations of all shelters and residential programs for youth, school truancy and exclusion practices and outcomes, child welfare service delivery by voluntary and public agencies, differentiated program experiences by region of the country, ethnicity, social class, and so forth. More difficult to obtain, but sorely needed, is information about children's rights, and the mechanisms through which these are assured.

\section{The Local Community}

Although federal policies and programs have played a critical role in stimulating changes in the processing of status offenders into and through the justice system, it is probable that this problem will not be solved without the development of effective alternative programs in the local community. A number of models for such community programs have already been designed and tested so that they provide guidance

\footnotetext{
${ }^{9}$ The current concerns about youth violence is one contemporary example of this phenomena where critical information is lacking and far-reaching decisions are being made about this problem. With respect to the problematic behavior of this type only the federal government is in a position to obtain and disseminate valid and reliable information, or at least to assume responsibility for its collection.
} 
for local action. The American Public Welfare Association (1977), Dixon and Wright (1976), Heasley (1975), Polk (1971), and Rosenheim (1960) have presented a variety of models for local services including Youth Service Bureau as the key component. Empey (1978) and his colleagues have described several programs that have relied heavily on guided group interaction technologies as a focal element. A variety of group homes and runaway shelter programs have been initiated to serve youth at risk because of non-criminal misconduct (Bartollas \& Miller, 1978; Coates, Miller, \& Ohlin, 1978; and Vinter, Downs, \& Hall, 1976; Wolf, Phillips, \& Fixsen, 1974). And, more recently, outdoor adventure and alternative school programs have developed rapidly in many states (Krajick, 1978; Mann, Petronio, \& Gold, 1978).

Analysis of the policy and program recommendations of the above authors and others suggest several areas of consensus for effective programming. These include:

1. Diversion and deinstitutionalization and decriminalization must continue to be areas receiving continuing priority so that more resources will be available in all states.

2. Programs must aim to reduce coercive control, discipline, and punishment.

3. Programs must provide continuing and frequent links to community and must seek to reconcile youth, their families and their communities.

4. Programs must provide for the adolescent's need for self direction, growth, and opportunities to resolve identity crises. Goals must be achievable, and recognized by youth as being just and in their own interest, not merely to benefit society as a whole.

5. Programs must be geared to meet the variable needs and characteristics of communities and their youth. Particular attention is required to ensure the delivery of quality services at the time and in the places where they are needed.

6 . Continuing attention must be directed toward obtaining adequate resources. Diversion and other alternative programs often face critical survival problems because of resource limitations and over-reliance on non-renewable federal grants.

7. Community involvement is essential for successful programs, but that involvement must be planned for and sup- 
ported in accordance with variable sociocultural characteristics of communities.

8. The final structure of a youth services system is dependent upon the political processes operative in a particular community. Obviously, there will be great variation within and among states. Federal assistance and support need to be planned with awareness of this contingency, but accountability need not be jeopardized by highly differentiated structural patterns.

\section{Conclusion}

Recent disturbances in many urban communities plus the rapidly growing problems of substance abuse, teenage pregnancy, and family conflict alarm all Americans. But, the solutions do not lie in more coercive control and incarceration, for then the cure may be worse than the illness. Youth urgently need opportunity for greater access to legitimate social roles. Services must be provided with greater attention to humaneness, fairness and justice. Many youth-serving agencies, public and private, have abdicated their responsibilities to adolescent youth with the result that ever increasing numbers are being processed through the juvenile justice system, held in punitive adult jails and detention, and then institutionalized in various types of asylums.

Too often the United States has waited to develop programs after serious problems have arisen; a "Band-Aid" solution will not be adequate for the problems which confront us in the areas of employment, mental health, delinquency, family dissolution and inadequate parenting, declining educational performance, and substance abuse. Most of our experience in solving social problems of this magnitude suggests that epidemiological and comprehensive services are required. Social policies are required which accept the reality of the contemporary situation and then establish realistic goals and priorities for a post-industrial society. Youth-serving organizations must then act to facilitate implementation of the programs necessary for adolescent socialization that will increase the achievement of those goals. 


\section{References}

American Public Welfare Association. Youth-community coordination project. Washington, D.C.: APWA, 1977.

Arthur, L. Status offenders need help too. Juvenile Justice, 1975, 26, 3-8.

Baron, R., \& Feeney, F. Preventing delinquency through diversion: The Sacramento County Probation Department 681 Diversion Project. Davis, California: University of Califonia, 1972.

Bartollas, C., \& Miller, S. The juvenile offender: Control, correction and treatment. Boston: Allyn Bacon, 1978.

Carter, T. Juvenile court depositions: A comparison of status and nonstatus offenders. Criminology, 1979, 17, 341-360.

Clarke, S. Getting 'em out of circulation: Does incarceration of juvenile offenders reduce crime? Journal of Criminal Law and Criminology, 1974, 65, 528-535.

Clarke, S.H. Status offenders are different from delinquents. In R. Allinson (Ed.), Status offender and the juvenile justice system. Hackensack, N.J.: NCSD, 1978, 100-109.

Coates, R., Miller, A., \& Ohlin, L. Diversity in a youth correctional system: Handling delinquents in Massachusetts. Cambridge: Ballinger, 1978.

Comment. Ungovernability: The unjustifiable jurisdiction. Yale Law Journal, $1974,83,1383-1409$.

Community Welfare Council. Hennepin County's status offenders: A preliminary report. Minneapolis: 1976.

Constanzo, P., \& Shaw, M. Conformity as a function of age level. Child Development, 1966, 37, 967-975.

Dixon, M., \& Wright, W. Evaluation of delinquency programs. In P. Boesen and S. Grupp (Eds.), Community-based corrections: Theory, practice and research. Santa Cruz, California: Davis, 1976.

Donzelot, J. The policing of families. New York: Pantheon, 1979.

Empey, L. American delinquency: Its meaning and construction. New York: Free Press of Macmillan, 1978.

Erikson, E. Identity, youth and crises. New York: W. W. Norton, 1967.

Gold, M., \& Reimer, D.J. Changing patterns of delinquent behavior among Americans 13 through 16 years old: 1967-72. Crime and Delinquency Literature, 1975, 7, 483-517.

Gordon, J.S. Caring for youth. Washington, D.C.: U.S. Dept. of Health, Education, and Welfare, 1978.

Gough, A. Processing status offenders. In L. Teitelbaum \& A. Gough (Eds.), Beyond control: Status offenders in the juvenile court. Cambridge, Mass.: Ballinger, 1978.

Grichting, W. The state and fate of status offenders. Ann Arbor, Mich.: National Assessment of Juvenile Corrections. Unpublished paper, 1975.

Heasley, C.W. The Mecklenburg Youth Services Bureau report. Charlotte, North Carolina: Mecklenburg Youth Services Bureau, 1975.

Heuser, J.P. Are status offenders really different? Salem, Oregon: Oregon Law Enforcement Council, 1979. 
Heyns, R. Personal communication, The University of Michigan, Ann Arbor, Michigan, 1976.

Institute of Judicial Administration. The Ellery C. decision: A case study of judicial regulation of status offenders. New York: Institute of Judicial Administration, 1975.

Isenstadt, P., Selo, E., \&c Barton, W. Status offenders in correctional programs. (Report to the Department of Health, Education and Welfare.) Ann Arbor: University of Michigan, NAJC, 1976.

Juvenile Justice Digest. Discrimination shows against femaie juveniles in Louisville, Juvenile Justice Digest, 1976, 4.

Keniston, K. The emptying family. New York Times, 1976, 33.

Krajick, K. Working our way home. Corrections, 1978, 4(2), 32-47.

Lemert, E. Records in the juvenile court. In Stanton Wheeler (Ed.), On record: Files and dossiers in American life. New York: Russell Sage, 1969.

Lerman, P. Delinquency and social policy. New York: Praeger Publications, 1970.

Lerman, P. Trends and issues in the deinstitutionalization of youths in trouble. Crime and Delinquency, 1980, 26(3), 333-343.

Levin, M., \& Sarri, R. Juvenile delinquency: A comparative analysis of legal codes in the United States. Ann Arbor, Michigan: The University of Michigan, NAJC, 1974.

Levine, R.S. Caveat Parens: A demystification of the child protection system. University of Pittsburgh Law Review, 1973, 35, 1-52.

Lynch, J.P., Korbelik, J., \& Spergel, I. Preliminary analysis: Juvenile offense decisions cohort in selected Chicago communities and Decatur: Time I. Chicago, Illinois: University of Chicago School of Social Services Administration, 1977.

Mahoney, A.R. The effect of labelling upon youths in the juvenile justice system: A review of the evidence. Law and Society, 1974, 8, 1-52.

Mann, D., Petronio, R., \& Gold, M. Alternative schools: A research strategy. Ann Arbor, Michigan: Institute for Social Research, 1978.

Melekos, I. Juvenile justice: Who gets what, when and how. The University of Michigan. National Assessment of Juvenile Corrections. Unpublished, 1976.

Michigan Department of Social Services. Decentralized delinquency services in Michigan: Differential placement and its impact on program effectiveness and cost-effectiveness. Lansing, Michigan: Department of Social Services, 1975.

National Center for Juvenile Justice. Delinquency 1977 U.S. estimates of cases processed by juvenile courts with juvenile jurisdiction. Pittsburgh: National Center for Juvenile Justice, 1980.

Pennsylvania Joint Council on the Criminal Justice System. The juvenile status offender and the law. Harrisburg, Pa.: Joint Council on the Criminal Justice System, 1977.

Piliavin, I., \& Briar, S. Police encounters with juveniles. American Journal of Sociology, 1964, 70, 206-214.

Polk, K. Delinquency prevention and the youth services bureau. Criminal Law Bulletin, 1971, 7, 490-6. 
Rosenheim, M. Youth services: A concept in search of a definition. Juvenile Judges Journal, 1969, 20, 69-74.

Sarri, R. Under lock and key. Ann Arbor: University of Michigan, National Assessment of Juvenile Corrections, 1974.

Sarri, R., \& Hasenfeld, Y. Brought to justice: Juveniles, the courts and the law. Ann Arbor, Michigan: University of Michigan, NAJC. 1976.

Sarri, R., \& Vinter, R. Juvenile injustice: The failure of a nation. Paper presented at the National Conference of Directors of Criminal Justice Research Centers, Harvard Law School, 1974.

Schach, E. The PINS child-A plethora of problems. New York: Office of Children's Services, Judicial Conference of the State of New York, 1973.

Sheridan, W.H. Juveniles who commit noncriminal acts-why treat in a correctional system? Federal Probation, 1967, 31, 26-30.

Spergel, I., Lynch, J.P., Korbelik, J., \& Reamer, F.G. Evaluation of the Illinois status offender services project. University of Chicago: School of Social Service Administration, 1979.

Teitelbaum, L., \& Gough, A., (Eds.). Beyond control: Status offenders in the juvenile court. Cambridge, Mass.: Ballinger, 1978.

U.S. National Criminal Justice Information and Statistics Service. Children in custody: A report on the juvenile detention and correctional facility census of 1975. Washington, D.C.: Law Enforcement Assistance Administration, 1978.

Vinter, R., Downs, G., \& Hall, J. Juvenile corrections in the states: Residential programs and deinstitutionalization. Ann Arbor, Michigan: National Assessment of Juvenile Corrections, 1976.

Vinter, R., Kish, R., \& Newcomb, T. Time out: A study of juvenile correctional programs. Ann Arbor, Michigan: University of Michigan, NAJC, 1976.

Wald, P., \& Schwartz, L. Trying a juvenile right to treatment suit: Pointers and pitfalls for plaintiffs. American Criminal Law Review, 1974, 12, 125163.

Williams, J., \& Gold, M. From delinquent behavior to official delinquency. Social Problems, 1972, 20, 209-229.

Westcott, D. The nation's youth: An employment perspective. Children and Youth Services Review, 1979, 1, 209-229.

Wolf, M., Phillips, E., \& Fixsen, D. Achievement place phase II. Manhattan, Kansas: Department of Human Development, 1974. 